\title{
Protective Effects of Sanjoinine A against $N$-Methyl-D-aspartate-Induced Seizure
}

\author{
Yuan MA, ${ }^{a}$ Sung-Ryul Yun, ${ }^{b}$ Sang-Yoon NAm, ${ }^{c}$ Yun-Bae KIM,,${ }^{c}$ Jin-Tae Hong, ${ }^{b}$ Younghoon KIM, ${ }^{d}$ \\ Heesuk CHOI, ${ }^{d}$ Kinam LeE, ${ }^{d}$ and Ki-Wan $\mathrm{OH}^{*}, b$ \\ ${ }^{a}$ Research Institute of Veterinary Medicine, Chungbuk National University; ${ }^{b}$ College of Pharmacy, Chungbuk National \\ University; ${ }^{c}$ College of Veterinary Medicine, Chungbuk National University; Cheongju 361-763, South Korea: and \\ ${ }^{d}$ College of Oriental Medicine, Wonkwang University; Iksan 570-749, South Korea. \\ Received April 7, 2008; accepted June 21, 2008; published online June 27, 2008
}

Sanjoinine $A$ is a component of the alkaloid fraction of Zizyphi Spinosi Semen. This experiment was performed to investigate whether sanjoinine $A$ acts as an anticonvulsive in the $N$-methyl-D-aspartate (NMDA)-induced experimental seizure model. We also examined whether it protects against seizure-form electroencephalogram (EEG) alterations induced by NMDA in vivo and/or cell killing due to NMDA in cultured cerebellar granule cells. Administration of sanjoinine $A$ increased the survival rate and the latency of seizure onset, and decreased the seizure scores and the weight-loss induced by NMDA in mice, in a dose-dependent manner. In addition, sanjoinine A blocked seizure-form EEG alterations induced by NMDA and inhibited NMDA-induced cell killing in cultured rat cerebellar granule cells, measured by both the trypan blue exclusion test and the 3-[4,5-dimethylthiazol-2-yl]-2,5-diphenyltetrazolium bromide (MTT) assay. Moreover, sanjoinine A inhibited the elevation of intracellular calcium influx induced by NMDA, which was measured using a fluorescent dye, Furo 3-AM. It is suggested that sanjoinine A protects against NMDA-induced seizures by inhibiting intracellular calcium influx.

Key words Zizyphi Spinosi Semen (ZSS); sanjoinine A; seizure; $N$-methyl-D-aspartate; electroencephalogram; cerebellar granule cell $\left[\mathrm{Ca}^{2+}\right]_{i}$

Zizyphi Spinosi Semen (ZSS), the seeds of Zizyphus jujuba Mill. var. spinosa (Rhamnaceae), is one of the herbs traditionally used for the treatment of insomnia, anxiety, and childhood convulsions in oriental countries. ${ }^{1-5)}$ ZSS has been shown to have tranquilizer-like effects. ${ }^{6,7)}$ Researchers found that methanol extract of ZSS significantly increased sleeping time induced by hexobarbital or pentobarbital and that cyclopeptide alkaloids from ZSS are important in central nervous system (CNS) inhibition., ${ }^{2,8,9)}$ It was recently reported that methanol extract of ZSS also had anxiolytic effects and that GABA receptors might be involved in its mechanisms of action. ${ }^{2,10)}$ The alkaloid fraction and flavonoids from ZSS are considered to be the major active components that inhibit the CNS activity. ${ }^{11,12)}$

Glutamate is a major excitatory transmitter as well as an important neurotoxin in the CNS. ${ }^{13)}$ Elevated extracellular glutamate levels have been shown to profoundly affect neuronal activity by activating specific ionotropic and metabotropic glutamate receptors. Glutamate receptors of the $\mathrm{N}$-methyl-D-aspartate (NMDA) type play a critical role in the pathophysiology of epilepsy and numerous other neurological disorders. ${ }^{14)}$ Expression of a variety of seizure types depends on the activation of NMDA receptors. ${ }^{15,16)}$ NMDA receptor antagonists suppress seizures in several animal models.

Methanol extract of ZSS has been found to be effective in protecting against NMDA-induced excitatory neuronal cell damage. ${ }^{2)}$ Recent studies have shown that ZSS contains many pharmacologically active components that inhibit and/or protect the CNS. ${ }^{17)}$ We were therefore interested in whether sanjoinine A (Fig. 1), one of major alkaloid compounds from ZSS, is an anticonvulsant and/or protects against NMDA-induced neuronal cell damage.

\section{MATERIALS AND METHODS}

Extraction and Isolation of Sanjoinine A ZSS (300 g) purchased from an oriental drug store in Korea, was extracted three times with 11 of hexane in a reflux condenser for $24 \mathrm{~h}$. The residues were extracted with methanol for $24 \mathrm{~h}$, and this methanol extraction was evaporated to dryness by rotary evaporation. The solvent was removed by rotary evaporation and partitioned between 5\% hydrochloric acid $(60 \mathrm{ml})$ and ether $(50 \mathrm{ml})$. This aqueous acid solution was extracted three times more with ammonia hydrate $(\mathrm{pH} 9.0)$ and chloroform $(60 \mathrm{ml} \times 3)$. The alkaloid fractions in chloroform solution were combined, filtered through Whatman No. 1 filter paper, and concentrated using a rotary vacuum evaporator followed by lyophilization. The yield of the alkaloid fraction was about $0.03 \%(\mathrm{w} / \mathrm{w})$. Using combined flash column chromatography and preparative thin layer chromatography, fourteen alkaloids were isolated in a crystalline state from the alkaloid fraction of ZSS. The alkaloids were named sanjoinine A, B, C, etc. in order of increasing polarity. The isolation yields varied greatly, ranging from $1.4 \times 10^{3}$ to $5 \times 10^{6} \%$. The chemical structure of sanjoinine A was defined by a combination of chemical correlation methods and spectral analysis (Fig. 1). ${ }^{9)}$

Animals Groups of 20 ICR mice of both sexes (Samtako, Korea) weighing $22-25 \mathrm{~g}$ were used for the convulsant test. Male Sprague-Dawley (SD) rats (Samtako, Korea, weighting $200-250 \mathrm{~g}$ ) were used for electroencephalogram (EEG) recording. Animals were housed in acrylic cages $(45 \times 60 \times 25 \mathrm{~cm})$ with water and food available ad libitum under an artificial 12-h light/dark cycle (lights on at 7:00 a.m.) and at a constant temperature $\left(22 \pm 2^{\circ} \mathrm{C}\right)$. To ensure adaptation to the new environment, the mice were kept in the departmental holding room for 1 week before testing. This 


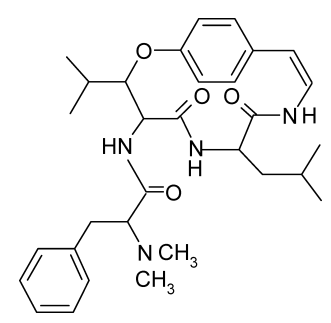

Fig. 1. Structure of Sanjoinine A

study was performed in accordance with the National Institute of Toxicological Research of the Korea Food and Drug Administration guidelines for the care and use of laboratory animals and each animal was used for one experiment only.

Agents and Administration NMDA (Sigma, St. Louis, MO, U.S.A.) and MK-801 (Sigma, St. Louis, MO, U.S.A.) were dissolved in physiological saline and administered intraperitoneally (i.p.) in a volume of $1 \mathrm{ml} / 100 \mathrm{~g}$ body weight. Sixty minutes prior to NMDA injection, sanjoinine A was administered orally (p.o.) with doses and pretreatment times obtained from preliminary studies in our laboratory. MK-801 were pretreated $30 \mathrm{~min}$ prior to NMDA injection. Convulsions were induced by injection of NMDA $(100 \mathrm{mg} / \mathrm{kg})$.

Assessment of Anticonvulsant Effects A modified method of Vellucci and Webster was used to assess the anticonvulsant effect of sanjoinine A. ${ }^{18)}$ Mice were kept individually in transparent mice cages $(25 \mathrm{~cm} \times 15 \mathrm{~cm} \times 15 \mathrm{~cm})$ for $30 \mathrm{~min}$ to acclimatize to their new environment before commencing the experiment. After NMDA $(100 \mathrm{mg} / \mathrm{kg})$ injection, convulsions were observed in animals for a period of $30 \mathrm{~min}$.

The number of surviving animals, onset of convulsion (latency), seizure score and weight loss were observed. ${ }^{18)}$ Mice were pretreated with MK-801 $(0.5 \mathrm{mg} / \mathrm{kg})$ or sanjoinine A before NMDA injection respectively. All experiments were carried out between 9:00 $\mathrm{h}$ and 16:00 $\mathrm{h}$ in a quiet room with an ambient temperature of $22 \pm 1^{\circ} \mathrm{C}$.

Surgery and Electroencephalogram Recording Rats were anesthetized with sodium pentobarbital $(45 \mathrm{mg} / \mathrm{kg}$ i.p.) and electrodes were implanted over the cortex using apparatus stereotaxic. The animals were allowed to recover for $7 \mathrm{~d}$ after the surgery. Electroencephalogram (EEG) apparatus (DSI, U.S.A.) and its corresponding software were used.

EEG recording was carried out in the plexiglas compartment. NMDA were injected $30 \mathrm{~min}$ after sanjoinine A $(4 \mathrm{mg} / \mathrm{kg}$, p.o. $)$ and MK-801 ( $0.5 \mathrm{mg} / \mathrm{kg}$, i.p.) administrations, respectively. Baseline EEG recordings were performed for $15 \mathrm{~min}$ before the NMDA $(100 \mathrm{mg} / \mathrm{kg}$, i.p.) treatment. Subsequently, EEG recordings were recorded continuously and behavioral observations were noted. Upon completion of the 60-min recording sessions, the animal was removed from the recording chamber and returned to its home cage. The EEG activity was evaluated using the program SleepSign (ver. 2.0). The power spectra were plotted and the integrated energy signals were expressed as $\mu \mathrm{V}^{2}$.

Cell Culture Primary cultures of cerebellar neurons enriched in granule cells were prepared from cerebella of $8 \mathrm{~d}$ old Sprague-Dawley rats as previously described. ${ }^{9)}$ Briefly, cells were plated $\left(1 \times 10^{6}\right.$ cells per $\left.0.2 \mathrm{ml}\right)$ in 96 microplates or $\left(2 \times 10^{6}\right.$ cells per $\left.2 \mathrm{ml}\right)$ in $60-\mathrm{mm}$ dishes that had been coated with poly-D-lysine $(10 \mu \mathrm{g} / \mathrm{ml})$ (Sigma, St. Louis, MO,
U.S.A.). The cells were cultured in basal Eagle's medium (Life Technologies, Gaithersburg, MD, U.S.A.) supplemented with $10 \%$ heat-inactivated fetal bovine serum (Life Technologies), $2 \mathrm{~mm}$ glutamine, gentamicin $(100 \mu \mathrm{g} / \mathrm{ml})$, antibiotic-antimycotic solution ( $10 \mathrm{ml} / \mathrm{l}$; Sigma, U.S.A.) and $25 \mathrm{~mm} \mathrm{KCl}$. This high concentration of potassium was necessary to induce persistent depolarization, which promotes the survival of granule cells. Cytosine arabinofuranoside $(10 \mu \mathrm{M}$ final concentration; Sigma, St. Louis, MO, U.S.A.) was added to cultures $18-24 \mathrm{~h}$ after plating to inhibit the proliferation of non-neuronal cells.

Measurement of Neuronal Cell Toxicity NMDA and MK-801 were solubilized in the incubation buffer described below. Sanjoinine A was dissolved in absolute ethanol with the concentration of $5 \mathrm{mg} / \mathrm{ml}$ and further diluted with the buffer. The final concentration of ethanol was $0.1 \%$, and did not affect cell viability (data not shown). Neurotoxicity experiments were performed on neurons grown for $8-10 \mathrm{~d}$ in vitro on either 12-well culture plates or 96-well microplates. The culture medium was removed and neurons were washed with a HEPES-buffered solution (incubation buffer) containing $8.6 \mathrm{~mm}$ HEPES, $154 \mathrm{~mm} \mathrm{NaCl}, 5.6 \mathrm{~mm} \mathrm{KCl}$ and $2.3 \mathrm{~mm}$ $\mathrm{CaCl}_{2}$, at $\mathrm{pH}$ 7.4. The cells were then incubated for $30 \mathrm{~min}$ in the same medium, and incubated for a further $3 \mathrm{~h}$ (unless otherwise indicated) in the presence of NMDA $(1 \mathrm{~mm})$ at $37^{\circ} \mathrm{C}$. To make sure the activation of the NMDA receptors, glucose and $\mathrm{Mg}^{2+}$ were omitted from the incubation buffer. In every experiment, sanjoinine A $(0.005,0.05$, and $0.5 \mu \mathrm{M})$ or MK$801(10 \mathrm{~mm})$ was added $15 \mathrm{~min}$ prior to the exposure of cells to NMDA and was present in the incubation buffer during NMDA exposure. Neuronal cell death was measured by trypan blue exclusion assay and MTT colorimetric assay.

Trypan Blue Exclusion Assay: After completion of incubation with NMDA (1 mM), the cells were stained with $0.4 \%$ (w/v) trypan blue solution $(400 \mu \mathrm{l} /$ well, prepared in $0.81 \%$ $\mathrm{NaCl}$ and $0.06 \% \mathrm{~K}_{2} \mathrm{HPO}_{4}$ ) at room temperature for $10 \mathrm{~min}$. Only dead cells with a damaged cell membrane are permeable to trypan blue. The numbers of trypan blue-permeable blue cells and viable white cells were counted in six randomly chosen fields per well under a phase contrast microscope (Olympus IX70, Tokyo, Japan). Cultures were pretreated with sanjoinine A or MK-801 $15 \mathrm{~min}$ prior to the NMDA treatment.

MTT Colorimetric Assay: This method is based on the reduction of the tetrazolium salt 3-[4,5-dimethylthiazol-2-yl]2,5-diphenyltetrazolium bromide (MTT) into a crystalline blue formazan product by cellular oxidoreductases. ${ }^{19)}$ The amount of formazan produced is proportional to the number of viable cells. After completion of incubation with NMDA ( $1 \mathrm{mM})$, the culture medium was replaced by a solution of MTT $(0.5 \mathrm{mg} / \mathrm{ml})$ in serum-free growth medium. After $4 \mathrm{~h}$ incubation at $37^{\circ} \mathrm{C}$, this solution was removed, and the resulting blue formazan was solubilized in $0.4 \mathrm{ml}$ of acid-isopropanol $(0.04 \mathrm{~N} \mathrm{HCl}$ in isopropanol). The optical density was read at $570 \mathrm{~nm}$ using a microplate reader (Bio-Tek ELX808, Vermont, U.S.A.). Serum-free growth medium was used for the blank solution. Cultures were pretreated with sanjoinine A or MK-801 $15 \mathrm{~min}$ prior to the NMDA treatment.

Measurement of Intracellular $\left[\mathrm{Ca}^{2+}\right]_{i}$ Concentration A confocal laser scanning microscope (Leica, TC-SP, Heidel- 
Table 1. Effects of Sanjoinine A on NMDA-Induced Convulsion

\begin{tabular}{|c|c|c|c|c|c|c|}
\hline \multicolumn{3}{|c|}{ Dose (mg/kg) } & \multirow{2}{*}{$\begin{array}{c}\text { No. of surviving animals/ } \\
\text { no. of animals used (\%) }\end{array}$} & \multirow{2}{*}{$\begin{array}{l}\text { Seizure } \\
\text { score }\end{array}$} & \multirow{2}{*}{$\begin{array}{l}\text { Latency to } \\
\text { convulsion(s) }\end{array}$} & \multirow{2}{*}{$\begin{array}{l}\text { Weight loss } \\
(\%)\end{array}$} \\
\hline NMDA & MK-801 & Sanjoinine A & & & & \\
\hline 100 & - & - & $13 / 20(65 \%)$ & $4.9 \pm 0.3$ & $612 \pm 91$ & $5.1 \pm 0.5$ \\
\hline 100 & 0.5 & - & $19 / 20(95 \%)$ & $1.8 \pm 0.4 * * *$ & $1392 \pm 106^{* * *}$ & $1.4 \pm 0.5 * * *$ \\
\hline 100 & - & 2 & $15 / 20(75 \%)$ & $3.6 \pm 0.4^{*}$ & $729 \pm 121$ & $4.4 \pm 2.5$ \\
\hline 100 & - & 4 & $16 / 20(80 \%)$ & $2.8 \pm 0.5^{* * *}$ & $965 \pm 126^{*}$ & $2.8 \pm 0.7^{*}$ \\
\hline 100 & - & 8 & $17 / 20(85 \%)$ & $2.4 \pm 0.5 * * *$ & $1089 \pm 146^{* *}$ & $1.9 \pm 0.5^{* * *}$ \\
\hline
\end{tabular}

$* p<0.05 v s$. NMDA $(100 \mathrm{mg} / \mathrm{kg}$, i.p.) control group. $* * p<0.01 v s$. NMDA $(100 \mathrm{mg} / \mathrm{kg}$, i.p.) control group. $* * * p<0.005 v s$. NMDA (100 mg/kg, i.p.) control group.

berg, Germany) was used to evaluate relative changes in intracellular $\mathrm{Ca}^{2+}$ concentration $\left(\left[\mathrm{Ca}^{2+}\right]_{i}\right.$ ) by monitoring Fluo-3 fluorescence after intracellular cleavage of superfused Fluo-3 AM ( $1 \mu \mathrm{M}$; Molecular Probes). Cells grown on glass cover slides were loaded with $1 \mu \mathrm{M}$ Furo 3 -AM for $45 \mathrm{~min}$ in DHanks solution at $37^{\circ} \mathrm{C}$ in the $\mathrm{CO}_{2}$ incubator, and washed with the incubation buffer. Baseline was recorded for $120 \mathrm{~s}$ prior to the addition of NMDA (1 mM). In order to test the effects of sanjoinine $\mathrm{A}$ and $\mathrm{MK}-801$ on NMDA-induced $\left[\mathrm{Ca}^{2+}\right]_{i}$ change, the cells were exposed to these compounds in the incubation buffer for $15 \mathrm{~min}$, after being loaded with Furo 3-AM and washed. The compounds were also present in the incubation buffer during the measurement of NMDAinduced $\left[\mathrm{Ca}^{2+}\right]_{i}$ change.

This experiment was carried out in the dark. Laser scanning was used to obtain a timed series of images with excitation at $488 \mathrm{~nm}$ and emission at $510 \mathrm{~nm}$, and an acquisition rate of 1 frame every $30 \mathrm{~s}$. The obtained images were quantitatively analyzed for changes in fluorescence intensities within a cell using Leica confocal software. Data were obtained by evaluating the fluorescence $(F)$ within a cell, subtracting the background fluorescence, and dividing by the fluorescence intensity before NMDA treatment (F0), expressed as F/F0. Control cultures had incubation buffer added. For the drug treatment groups, sanjoinine A $(0.0005$, $0.005,0.05 \mu \mathrm{M})$ or MK-801 $(10 \mu \mathrm{M})$ was added to the incubation buffer $15 \mathrm{~min}$ before and during recording.

Statistical Analysis Results are presented as mean \pm S.E.M. Data were analyzed using one-way analysis of variance (ANOVA) and Dunnett's post hoc multiple comparison tests. The analysis of the number of survival animals was done using the Chi-squared test.

\section{RESULTS}

Protective Effects of Sanjoinine A on NMDA-Induced Convulsions NMDA $(100 \mathrm{mg} / \mathrm{kg}$, i.p.) elicited convulsions in $100 \%$ of the mice. Pretreatment with MK-801 $(0.5 \mathrm{mg} / \mathrm{kg}$, i.p.) significantly decreased the number of mice that died and the seizure score in NMDA-treated mice. Similarly, administration of sanjoinine A $(2,4,8 \mathrm{mg} / \mathrm{kg}$, p.o. $)$ significantly decreased seizure score in NMDA-treated mice. Sanjoinine A $(4,8 \mathrm{mg} / \mathrm{kg}$, p.o. $)$ also increased the latency of seizure onset and reduced the loss of body weight in NMDA-treated mice (Table 1).

Effects of Sanjoinine A on Seizure-Form EEG Activity Induced by NMDA NMDA treatment induced intense high amplitude electrical seizure discharges in the anterior cortex, which usually occurred simultaneously with behav-
A

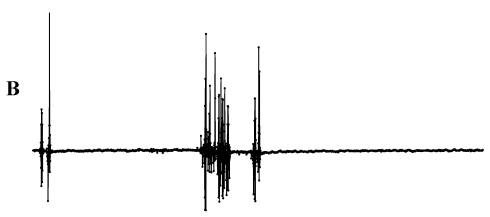

C

D

Fig. 2. Effects of Sanjoinine A on Electrical Seizure Discharges in Cortex Sanjoinine A or MK-801 was administered 30 min before NMDA injection. A: control; B: NMDA (100 mg/kg) injection; C: MK-801 $(0.5 \mathrm{mg} / \mathrm{kg})+\mathrm{NMDA}(100 \mathrm{mg} / \mathrm{kg})$; D: sanjoinine A $(4.0 \mathrm{mg} / \mathrm{kg})+\mathrm{NMDA}(100 \mathrm{mg} / \mathrm{kg})$.

ioral seizures. Continually registered EEG changes were in the form of sporadic isolated waves, which progressed into a series of synchronized poly-spikes, characterized by uninterrupted bursts of a high-voltage amplitude spikes $(1-8 \mathrm{mV})$. The EEG power spectra increased and became intense during seizure events. After MK-801 or sanjoinine A pretreatment, electrical seizure activity was markedly inhibited and only a few low amplitude seizure discharges were detected. (Figs. 2, $3)$.

Protection of Neuronal Cell Death by Sanjoinine A The number of cells with plasma membrane damage, as evidenced by trypan blue staining, significantly increased with exposure of the cells to NMDA. In control cultures, the number of trypan blue negative cells reached $93.3 \pm 0.4 \%$, while treatment with $1 \mathrm{mM}$ NMDA reduced this value to only $35.9 \pm 2.3 \%$. Sanjoinine A $(0.05,0.5 \mu \mathrm{M})$ significantly inhibited the increase of neuronal cell death induced by NMDA. MK-801 $(10 \mu \mathrm{M})$, an NMDA receptor antagonist, also caused a marked inhibition of NMDA-induced neuronal cell death (Table 2).

When cerebellar granule neurons were exposed to NMDA (1 $\mathrm{mM})$, the MTT reduction rate decreased to $65.8 \pm 1.6 \%$. Sanjoinine A $(0.05,0.5 \mu \mathrm{M})$ significantly reduced this decrease in cell viability induced by NMDA, with MTT reduc- 

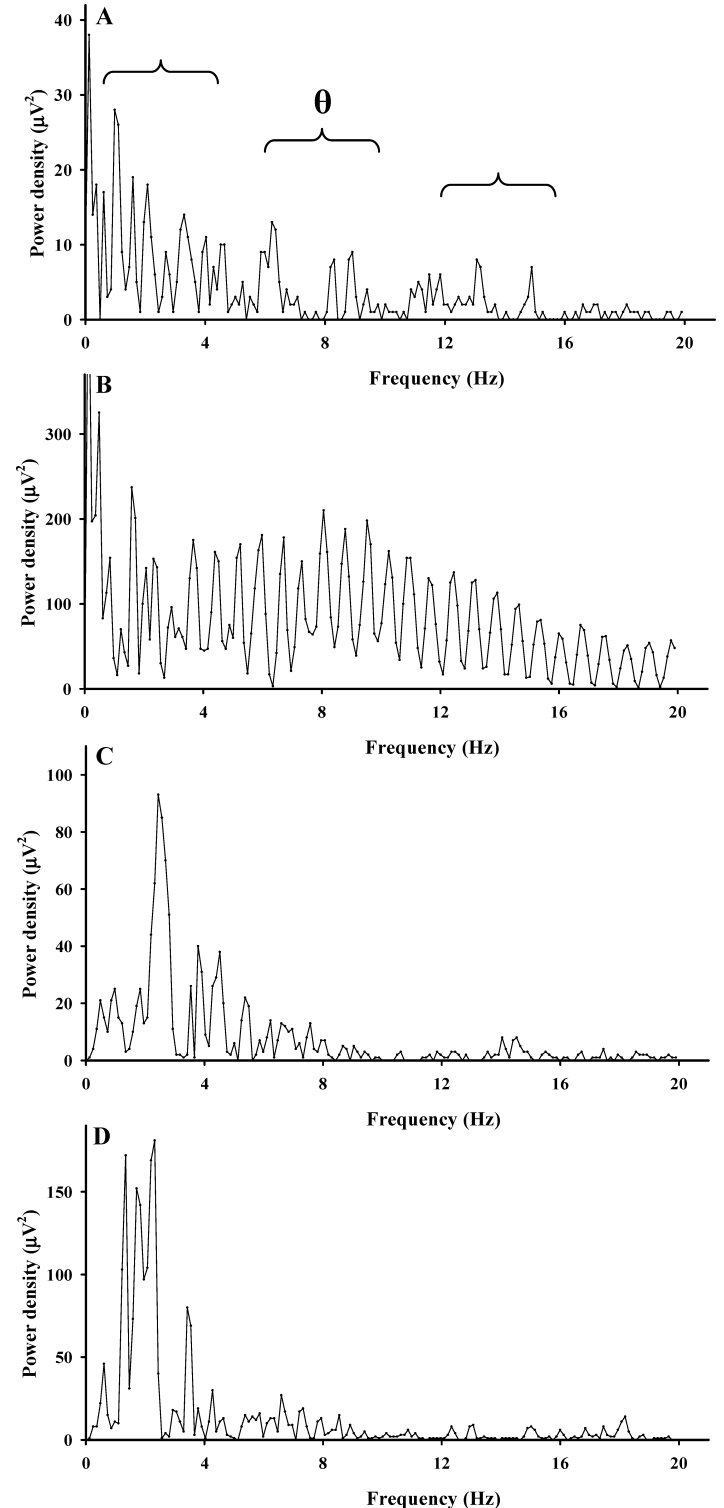

Fig. 3. Effects of Sanjoinine A on Power Spectra of EEG in Cortex

Sanjoinine A or MK- 801 was administered $30 \mathrm{~min}$ before NMDA injection. A: control; B: NMDA $(100 \mathrm{mg} / \mathrm{kg})$ injection. C: MK-801 $(0.5 \mathrm{mg} / \mathrm{kg})+$ NMDA $(100 \mathrm{mg} / \mathrm{kg})$; D: sanjoinine A $(4.0 \mathrm{mg} / \mathrm{kg})+\mathrm{NMDA}(100 \mathrm{mg} / \mathrm{kg})$

Table 2. Effects of Sanjoinine A on NMDA-Induced Neuronal Cell Death (Trypan Blue)

\begin{tabular}{lccc}
\hline \hline \multicolumn{1}{c}{ Group } & $\begin{array}{c}\text { Concentration } \\
\text { of } \\
\text { treatment }\end{array}$ & $n$ & $\begin{array}{c}\text { Cell viability (ratio } \\
\text { of trypan blue } \\
\text { negative cells) }\end{array}$ \\
\hline Control & - & 12 & $93.3 \pm 0.4$ \\
NMDA & $1 \mathrm{mM}$ & 12 & $35.9 \pm 2.3^{* *}$ \\
NMDA+MK-801 & $10 \mu \mathrm{M}$ & 12 & $73.5 \pm 2.0^{\# \#}$ \\
NMDA+Sanjoinine A & $0.005 \mu \mathrm{M}$ & 12 & $37.2 \pm 1.9$ \\
& $0.05 \mu \mathrm{M}$ & 12 & $51.2 \pm 2.1^{\# \#}$ \\
& $0.5 \mu \mathrm{M}$ & 12 & $52.9 \pm 1.5^{\# \#}$ \\
\hline
\end{tabular}

$* * p<0.01 v s$. control. \#p $p 0.01$ vs. NMDA 1 mM treated group.

tion rates of $73.4 \pm 2.2 \%$ and $77.1 \pm 2.4 \%$ respectively (Table 3). Similarly, MK-801 $(10 \mu \mathrm{M})$ significantly inhibited the decrease of the MTT reduction rate caused by NMDA.

Inhibition of NMDA-Induced Elevation of Intracellular $\left[\mathrm{Ca}^{2+}\right]_{i}$ by Sanjoinine A Intracellular $\left[\mathrm{Ca}^{2+}\right]_{i}$ started to el-
Table 3. Effects of Sanjoinine A on NMDA-Induced Neuronal Cell Death (MTT)

\begin{tabular}{lccc}
\hline \hline \multicolumn{1}{c}{ Group } & $\begin{array}{c}\text { Concentration } \\
\text { of treatment }\end{array}$ & $n$ & $\begin{array}{c}\text { Cell survival } \\
\text { (\% of control) }\end{array}$ \\
\hline Control & - & 15 & $100.0 \pm 3.5$ \\
NMDA & $1 \mathrm{mM}$ & 16 & $42.8 \pm 2.8^{* *}$ \\
NMDA+MK-801 & $10 \mu \mathrm{M}$ & 19 & $71.9 \pm 6.7^{\text {\#\# }}$ \\
NMDA+Sanjoinine A & $0.005 \mu \mathrm{M}$ & 16 & $43.2 \pm 5.0$ \\
& $0.05 \mu \mathrm{M}$ & 16 & $54.6 \pm 4.7^{\#}$ \\
& $0.5 \mu \mathrm{M}$ & 14 & $70.0 \pm 6.4^{\# \#}$ \\
\hline
\end{tabular}

$* * p<0.01$ vs. control. $\# p<0.05$ vs. model (NMDA $1 \mathrm{~mm}$ ) group. \#p<0.01 vs. model (NMDA $1 \mathrm{~mm}$ ) group.

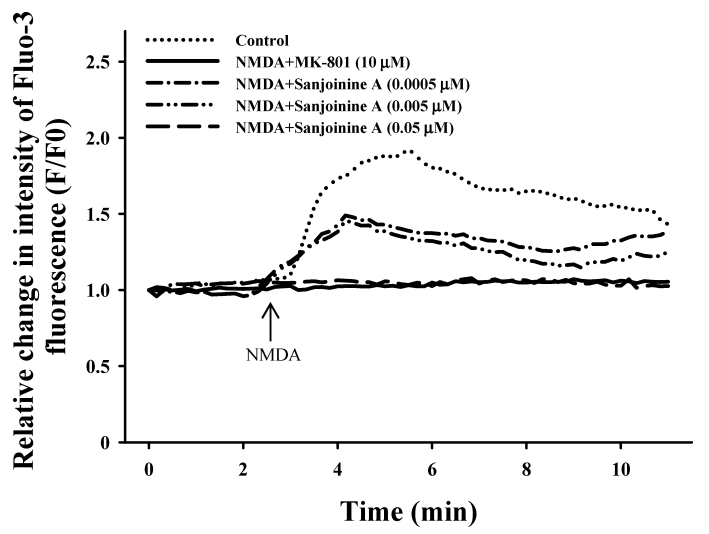

Fig. 4. Change of $\left[\mathrm{Ca}^{2+}\right]_{i}$ in Response to NMDA in the Presence or Absence of Sanjoinine A or MK-801 in Cultured Granule Neurons

Intracellular $\left[\mathrm{Ca}^{2+}\right]_{i}$ was monitored using a laser scanning confocal microscope. Results are expressed as the relative fluorescence intensity (F/F0). Each trace represents $\mathrm{F} / \mathrm{F} 0$ value from a representative cell population.

evate immediately after treatment with $1 \mathrm{~mm}$ NMDA and the fluorescence reached maximal intensity after $3-4 \mathrm{~min}$. Neither sanjoinine A or MK-801 affected basal $\left[\mathrm{Ca}^{2+}\right]_{i}$. However, both sanjoinine A $(0.05 \mu \mathrm{M})$ and MK-801 $(10 \mu \mathrm{M})$ blocked the increase of intracellular $\left[\mathrm{Ca}^{2+}\right]_{i}$ induced by NMDA (Fig. 4).

\section{DISCUSSION}

Epilepsy is a chronic neurological disorder characterized by recurrent seizures, which is estimated to affect $1-2 \%$ of the world population. ${ }^{20)}$ Numerous data indicate that enhanced excitatory amino acid (EAA)-mediated neurotransmission plays a significant role in the development of seizure activity. ${ }^{21,22)}$ Glutamate is the major excitatory transmitter as well as an important neurotoxin in the CNS. ${ }^{13,23,24)}$ Elevated extracellular glutamate levels have been shown to profoundly affect neuronal activity by activating specific ionotropic and metabotropic receptors and have been implicated in neurodegenerative processes associated with convulsion, ischemia and other neuropathological conditions. ${ }^{25)}$ The experimental application of ionotropic glutamate receptor agonists, either peripheral or intracerebral, induces convulsions in rodents. ${ }^{26,27)}$ Conversely, glutamate receptor antagonists display protective action and may prevent epileptogenesis in various experimental seizure models. However, their use is associated with a number of side effects. ${ }^{28)}$ EAA antagonists may also enhance the anticonvulsant activity of conventional antiepileptic drugs, and such combined treatment seems ben- 
eficial in terms of reduced adverse effects. ${ }^{29-32)}$

The NMDA receptor is one of the main glutamate receptors and plays an essential role in the seizure-triggering mechanism in experimentally elicited seizures. ${ }^{33,34)}$ Activation of NMDA receptors in the CNS also contributes to many aspects of neuronal signaling and excitatory neuron damage. NMDA receptor antagonists have been shown to block or delay seizure activity in rats and mice, suggesting a role for NMDA receptor activation in epileptogenesis. ${ }^{16,35)}$

NMDA is a specific agonist of these NMDA receptors implicated in the pathogenesis of convulsion. NMDA produces effects similar to glutamate acid at NMDA receptors and exerts its convulsant effects by activating the receptors to enhance glutamatergic neuro-transmission. In most of the published studies, NMDA antagonists were found capable of preventing seizures and lethality induced by multiple chemicals. $^{36-40)}$ Similarly, in the present study, NMDA induced convulsions in mice and MK-801 significantly protected against these convulsions. Sanjoinine A was also effective in preventing the occurrence of EEG seizure-form activity in NMDA-treated rats. Sanjoinine A given $30 \mathrm{~min}$ before NMDA exerted a notable anticonvulsant activity antagonizing convulsing spike-wave complexes in NMDA-treated rats. Since glutamatergic transmission through NMDA receptors is involved in the generation and propagation of seizure-related neuronal discharges, it is possible therefore that sanjoinine A may in some way interfere with the glutamatergic mechanism to protect against NMDA-induced convulsions. It is also possible that sanjoinine A may affect inhibitory systems in the CNS, such as the gamma aminobutyric acid (GABA)-ergic system, to exert its anticonvulsant effects. ${ }^{41)}$

There is a great deal of data showing that activation of NMDA receptors elevates the influx of $\mathrm{Ca}^{2+}$ and of nonNMDA receptors promotes the influx of $\mathrm{Na}^{+}$, which can lead to membrane depolarization. In turn, depolarization can activate membrane voltage-sensitive $\mathrm{Ca}^{2+}$ channels, leading to additional $\mathrm{Ca}^{2+}$ influx. Many studies have shown that NMDA-induced elevation of $\left[\mathrm{Ca}^{2+}\right]_{i}$ plays a fundamental role in the process of excitotoxicity. ${ }^{42,43)}$ Transient increases in $\left[\mathrm{Ca}^{2+}\right]_{i}$ induced by NMDA can result from the entry of $\mathrm{Ca}^{2+}$ from receptor-operated channels, voltage-activated channels, or from the release of $\mathrm{Ca}^{2+}$ from internal stores. A sustained increase in $\left[\mathrm{Ca}^{2+}\right]_{i}$ triggers a series of events including elevation of cGMP, glutamate release and activation of NOS. ${ }^{44,45)}$

Numerous studies have related ionotropic glutamate receptors to the regulation of neuron survival, in vivo as well as in vitro. In most cases, exposure to agonists of glutamate receptors has been reported to lead to increased cell death, whereas antagonists were found to be protective. ${ }^{42,46-48)}$ While it is now clear that both kainate and amino-3-hydroxy5-methylisoxazole-4-propionic acid (AMPA) receptors are involved, ${ }^{47,49-51)}$ NMDA receptors were the first to be considered as having a role in this domain. ${ }^{46,48)}$ Neurotoxicity initiated by over-stimulation of NMDA receptors and the subsequent influx of free $\mathrm{Ca}^{2+}$ leads to an intracellular cascade of cytotoxic events. ${ }^{42} \mathrm{Ca}^{2+}$-dependent depolarization of mitochondria has been suggested to contribute to oxidative stress in neuronal injury. ${ }^{42,52)}$

The cerebellum is closely related to seizure onset. Researchers found that the glutamatergic signaling pathway in the cerebellum changed with seizure form behaviours. ${ }^{53-55)}$ The cultured rat cerebellar granule cell has been one of the methods commonly used in investigation of seizure mechanisms and its relationship with functions of GABAergic systems and NMDA receptor, it was also commonly used to evaluate antiseizure effects and mechanisms of different compounds. ${ }^{56)}$ A previous study indicated that methanol extract of ZSS was neuroprotective against NMDA-induced cell death. ${ }^{2)}$ It also blocked the NMDA-induced increase in $\left[\mathrm{Ca}^{2+}\right]_{i}$, glutamate release and ROS generation. ${ }^{2)}$ In the present study, sanjoinine A significantly protected neurons against NMDA-induced cell death and blocked the NMDAinduced increase of $\left[\mathrm{Ca}^{2+}\right]_{i}$ at the concentration range studied. This indicates that sanjoinine $\mathrm{A}$ is at least one of the components of ZSS that are responsible for its CNS inhibitory or anticonvulsant effects. 0.05 and $0.5 \mu \mathrm{M}$ sanjoinine A exhibited similar inhibition in cerebellar granule cells as did $10 \mu \mathrm{M}$ MK-801, so was more potent. In the in vivo experiments, however, 4 and $8 \mathrm{mg} / \mathrm{kg}$ sanjoinine A had similar effects as $0.5 \mathrm{mg} / \mathrm{kg} \mathrm{MK}-801$, so was less potent in this system. The discrepancy between the results of the in vitro and in vivo experiments might be due to blood brain barrier transportation of sanjoinine $\mathrm{A}$ in the in vivo test. Sanjoinine A $(0.05 \mu \mathrm{M})$ completely inhibited NMDA-induced $\left[\mathrm{Ca}^{2+}\right]_{i}$, but only partially inhibited NMDA-induced neuronal death, which indicated that sanjoinine A may specifically influence $\mathrm{Ca}^{2+}$-dependent, but not $\mathrm{Ca}^{2+}$-independent, pathways of NMDA receptors. ${ }^{57)}$

The mechanisms underlying convulsant action may involve multiple targets, including activation of the glutamatergic system. This is the main excitatory neurotransmitter system in the CNS of mammals, ${ }^{58)}$ and participates in various neuropathological disorders, including epilepsy. ${ }^{34)}$ Of the many molecular mechanisms through which anticonvulsant drugs exert their effect, the majority of currently available drugs primarily work by antagonizing $\mathrm{Na}^{+}$or $\mathrm{Ca}^{2+}$ channels, inhibiting glutamate receptors, or facilitating GABAergic inhibition. ${ }^{59)}$ Our previous research had already demonstrated that sanjoinine A could influence expression of $\mathrm{GABA}_{\mathrm{A}}$ receptor subunits and glutamate acid decarboxylase (GAD) in cultured granule neurons. $\left.{ }^{9}\right)$ Our current results further suggest that sanjoinine A could exert its anticonvulsant effects through inhibition of $\mathrm{Ca}^{2+}$ influx activated by NMDA receptors. Although it is still unclear from our data whether sanjoinine A exerts its antiseizure and neuron protective effects directly through NMDA receptors, it is possible that sanjoinine A may at least downregulate the excitatory effects of NMDA by stimulation of GABAergic systems. ${ }^{41,60-62)}$ Sanjoinine A is effective in activating $\mathrm{GABA}_{\mathrm{A}}$ receptors, increasing GAD levels and increasing chloride influx in cultured neurons.9) The chloride channel of the $\mathrm{GABA}_{\mathrm{A}}$ receptor is responsible for the rapid hyperpolarization, and activation of $\mathrm{GABA}_{\mathrm{A}}$ receptor could induce opening of chloride channel and subsequent hyperpolarization, which could block the excitatory effects induced by NMDA. ${ }^{63)}$ Sanjoinine A could be considered as a hopeful candidate for treatment of epilepsy or convulsions.

In conclusion, all the data presented here indicate that the sanjoinine A has considerable anticonvulsant effects. The NMDA receptor-mediated neuroprotection by sanjoinine A may help to explain at least some of its central inhibitory ac- 
tions such as its anticonvulsive effect. It is also possible that there might be multiple mechanisms involved in its anticonvulsant effects, in particular relating to functions of GABAergic and/or glutamatergic systems. Further investigation is needed in order to understand the pharmacological actions of sanjoinine A.

Acknowledgements This work was supported by the Korea Research Foundation Grant funded by the Korean Government (MOEHRD, Basic Research Foundation Fund) (KRF-2005-005-J15002).

\section{REFERENCES}

1) Ahn N. Y., Jung J. W., Oh H. R., Shin J. S., Hyeon S. Y., Lee B. K., Cheong J. H., Ryu J. H., J. Appl. Pharmacol., 12, 151-156 (2004).

2) Park J. H., Lee H. J., Koh S. B., Ban J. Y., Seong Y. H., J. Ethnopharmacol., 95, 39-45 (2004).

3) Han Y. N., Hwang K. H., Han B. H., Arch. Pharm. Res., 28, 159-163 (2005).

4) Zhao J., Li S. P., Yang F. Q., Li P., Wang Y. T., J. Chromatogr., 1108, 188-194 (2006).

5) Chauhan A. K., Dobhal M. P., Joshi B. C., J. Ethnopharmacol., 22 , $11-23(1988)$

6) Han H., Ma Y., Eun J. S., Hong J. T., Oh K. W., J. Appl. Pahramcol., 15, 175-181 (2007)

7) Kawashima K., Saito K., Yamada A., Obara S., Ozaki T., Kano Y., Biol. Pharm. Bull., 20, 1171-1174 (1997).

8) Adzu B., Amos S., Dzarma S., Wambebe C., Gamaniel K., J. Ethnopharmacol., 79, 13-16 (2002).

9) Ma Y., Han H., Eun J. S., Kim H. C., Hong J. T., Oh K. W., Biol. Pharm. Bull., 30, 1748-1753 (2007).

10) Peng W. H., Hsieh M. T., Lee Y. S., Lin Y. C., Liao J., J. Ethnopharmacol., 72, 435-441 (2000).

11) Heo H. J., Park Y. J., Suh Y. M., Choi S. J., Kim M. J., Cho H. Y., Chang Y. J., Hong B., Kim H. K., Kim E., Kim C. J., Kim B. G., Shin D. H., Biosci. Biotechnol. Biochem., 67, 1284-1291 (2003).

12) Suksamrarn S., Panseeta P., Kunchanawatta S., Distaporn T., Ruktasing S., Suksamrarn A., Chem. Pharm. Bull., 54, 535-537 (2006).

13) Chen H. S., Lipton S. A., J. Neurochem., 97, 1611-1626 (2006).

14) Cull-Candy S., Brickley S., Farrant M., Curr. Opin. Neurobiol., 11, 327-335 (2001).

15) Löscher W., Prog. Neurobiol., 54, 721-741 (1998).

16) Rice A. C., DeLorenzo R. J., Brain Res., 782, 240-247 (1998).

17) Kawai K., Akiyama T., Ogihara Y., Shibata S., Phytochemistry, 13 2829-2832 (1974).

18) Vellucci S. V., Webster R. A., Eur. J. Pharmacol., 97, 289-293 (1984).

19) Berridge M. V., Tan A. S., Arch. Biochem. Biophys., 303, 474- 482 (1993).

20) Locke C. J., Williams S. N., Schwarz E. M., Caldwell G. A., Caldwell K. A., Brain Res., 1120, 23-34 (2006).

21) Dávalos A., Shuaib A., Wahlgren N. G., J. Stroke Cerebrovasc. Dis., 9, $2-8(2000)$.

22) Riljak V., Jandová K., Langmeier M., Ceskoslov. Fysiol., 55, 115-122 (2006).

23) Römer K. D., Bleich S., Kornhuber J., Fortschr. Neurol.-Psychiatr., 71, S3-S9 (2003).

24) Carpenter K. J., Dickenson A. H., Curr. Opin. Pharmacol., 1, 57-61 (2001).

25) Rothman S. M., Olney J. W., Ann. Neurol., 19, 105-111 (1986).

26) Swiader M. J., Luszczki J. J., Zwolan A., Wielosz M., Pharmacol. Rep., 57, 373-379 (2005)

27) Chapman A. G., Prog. Brain Res., 116, 371-383 (1998).
28) Schoepp D. D., Gamble A. Y., Salhoff C. R., Johnson B. G., Ornstein P. L., Eur. J. Pharmacol., 182, 421-427 (1990).

29) Borowicz K. K., Kleinrok Z., Czuczwar S. J., Eur. Neuropsychopharmacol., 11, 61-68 (2001).

30) Czuczwar S. J., Turski W. A., Kleinrok Z., Metabol. Brain Dis., 1, 63-72 (1996).

31) Urbañska E. M., Czuczwar S. J., Kleinrok Z., Turski W. A., Restor Neurol. Neurosci., 13, 25-39 (1998).

32) Wojtal K., Borowicz K. K., Blaszczyk B., Czuczwar S. J., Pharmacol. Rep., 58, 587-598 (2006)

33) McNamara J. O., Trends Neurosci., 15, 357-359 (1992).

34) Meldrum B. S., J. Nutr., 130, S1007—S1015 (2000).

35) Lu W., Chen G., Cheng J. S., Neuroreport, 21, 4045 - 4049 (1998).

36) Makarska B. K., Kamiński R. M., Czuczwar S., J. Pharmacol. Rep., 57, 458- 466 (2005)

37) Yen W., Williamson J., Bertram E. H., Kapur., J. Epilepsy Res., 59, $43-50$ (2004)

38) Zivanovic D., Lovic O. S., Susic V., Indian J. Med. Res., 119, 79-85 (2004).

39) Mares P., Folbergrová J., Kubová H., Physiol. Res., 53, S115-S124 (2004).

40) Sparenborg S., Brennecke L. H., Jaax N. K., Braitman D. J., Neuropharmacology, 31, 357-368 (1992).

41) Malfatti C. R., Perry M. L., Schweigert I. D., Muller A. P., Paquetti L., Rigo F. K., Fighera M. R., Neuroscience, 146, 1879-1887 (2007).

42) Choi D. W., Neurosci. Lett., 5, 293 -297 (1985).

43) Mody I., MacDonald J. F., Trends Pharmacol. Sci., 16, 356-359 (1995).

44) Mei J. M., Chi W. M., Trump B. F., Eccles C. U., Mol. Chem. Neuropathol., 27, 155-166 (1996)

45) Btrons M. A., Saadoun S., Agullo L., J. Neurosci. Res., 49, 333-341 (1997).

46) Lesort M., Esclaire F., Yardin C., Hugon J., Neurosci. Lett., 221, 213 216 (1997)

47) Solum D., Hughes D., Major M. S., Parks T. N., J. Neurosci., 17, 4744-4751 (1997).

48) Drian M. J., Kamenka J. M., Privat A., J. Neurosci. Res., 57, 927—934 (1999).

49) Larm J. A., Cheung N. S., Beart P. M., Eur. J. Pharmacol., 314, 249254 (1996).

50) Larm J. A., Cheung N. S., Beart P. M., J. Neurochem., 69, 617-622 (1997).

51) Bardoul M., Drain M. J., Konig N., Perspect. Dev. Neurobiol., 5, 353-371 (1998)

52) Dykens J. A., J. Neurochem., 63, 584-591 (1994).

53) Park S. K., Hwang I. K., An S. J., Won M. H., Kang T. C., Mol. Cells, 16, 297-301 (2003).

54) Chen H. H., Lee Y. F., Chan M. H., Lo P. S., Ann. N.Y. Acad. Sci., 1025, 552-555 (2004)

55) Letwin N. E., Kafkafi N., Benjamini Y., Mayo C., Frank B. C., Luu T., Lee N. H., Elmer G. I., J. Neurosci., 26, 5277-5287 (2006).

56) Lin Y. R., Chen H. H., Ko C. H., Chan M. H., Neuropharmacology, 49, 542-550 (2005).

57) Ichinose T., Yu S., Wang X. Q., Yu S. P., J. Physiol., 551, 403-417 (2003).

58) Monaghan D. T., Cotman C. W., J. Neurosci., 5, 2909-2919 (1985).

59) Zaremba P. D., Białek M., Blaszczyk B., Cioczek P., Czuczwar S., J. Pharmacol. Rep., 58, 1-12 (2006).

60) Ge Z. J., Zhang L. C., Zeng Y. M., Da T. J., Wang J. K., Cui G. X., Tan Y. F., Zhao Y. P., Liu G. J., Pharmacology, 80, 127-133 (2007).

61) Pereira M. B., Freitas R. L., Assis M. A., Silva R. F., Fonteles M. M., Freitas R. M., Neurosci. Lett., 419, 253-257 (2007).

62) Devaud L. L., Alele P., Alcohol. Clin. Exp. Res., 28, 957-965 (2004).

63) Paladini C. A., Iribe Y., Tepper J. M., Brain Res., 832, 145-151 (1999). 